\title{
The Relation between Anxiety and Aggressivity Toward Karate Martial Arts Achievement in Male Athletes Kumite
}

\author{
Pangondian Hotliber Purba ${ }^{1}$, Rahman Situmeang ${ }^{2}$ \\ \{pangondianpurba@yahoo.co.id ${ }^{1}$, rahmansitumeang@gmail.com ${ }^{2}$ \} \\ Pendidikan Kepelatihan Olahraga, Universitas Negeri Medan, Jl. Willem Iskandar Psr V, Medan, \\ Indonesia ${ }^{1,2}$
}

\begin{abstract}
The study aim to examine (1) The relationship directly of the anxiety to sport performance in competitive male's karateka kumite, (2) The relationship directly of the aggressivity to sport performance in competitive male's karateka kumite, (3) The relationship Indirect of the anxiety to sport performance in competitive male's karateka kumite. One hundred and three males karateka kumite (20 \pm 2 years) participated in this study. Karateka were taken in Kejuaraan Nasional Antar Mahasiswa Sebelas Maret Cup VII in Surakarta. The research of methodology is the correlation descriptive. The results of study are (1) there is the relationship directly between the anxiety to sport performance in competitive male's karateka kumite. (2) there is the relationship directly between the aggressivity to sport performance in competitive male's karateka kumite. (3) there is the relationship indirectly between the anxiety to sport performance in competitive male's karateka kumite. The conclusion of this study, to achieve the anxiety and aggresivity exercises. Thus, hopefully the male karateka kumite can able to develop aggresivity and to control the behaviour of themself.
\end{abstract}

Keywords: Anxiety, Aggressivity, Sport Performance.

\section{Introduction}

In sport martial art "karate" the kumite event is need courage to attacking the opponents. The victory is not achieved of purely technical factor, but non-technical factors very influential by the mental aspects such as motivation, confidence, emotional, anxiety and aggressifity. The sport with full body contact requires courage to attack (Husdarta; 2010,76). Aggressiveness is absolutely necessary for every martial arts sport especially Karate. Sports performance is not only determined by physical aspects, techniques and tactics are also influenced by psychological factors (Bompa ;1994). Indonesia performance karateka In the championship of Cadets and Juniors Asian Karatedo Federation 10th in Hong Kong is bad while the other southeast asia countries get better result. Indonesia karateka contingent finished sixth, the winner is Iran, Japan in second, Kazakhstan third, Vietnam fourth and Malaysia in fifth. "A few years ago Indonesian was complacent and did nothing" said Hendardji Soepandji General Chairman of PB. Sports federation of Karate-Do Indonesia (FORKI), in 1970s to 1980s karate indonesia ever successful. 
Some of the national level coaches said Indonesia karateka is good as physical conditioning, technic, and tactics. But the ability is not supported by a strong mental so the highest performance will not be achieved. The mental make karateka better. The failure of the karateka caused of high level anxiety and low aggressiveness. During the fight, aggressive behavior is makes karateka get more courage to attact especially in the kumite event.

Rita Subowo, The Chairman KONI/KOI said the high level of anxiety Indonesia Karateka become one of the failure factors to achieve gold medal in the Asian Games XVI/2010 in Guangzhou. The level of competition affect the mental of athletes and build of high levels of anxiety and loss of confidence. High anxiety make athletes to be not optimal, and it is very reasonable because they want to offer the best performance for Indonesia. The study aim to examine (1) The relationship directly of the anxiety to sport performance in competitive male's karateka kumite, (2) The relationship directly of the aggressivity to sport performance in competitive male's karateka kumite, (3) The relationship Indirect of the anxiety to sport performance in competitive male's karateka kumite. The purpose of this study are (1) To find out therelationship directly of the anxiety to sport performance in competitive male's karateka kumite, (2) To find out the relationship directly of the aggressivity to sport performance in competitive male's karateka kumite, (3) To find out the relationship Indirect of the anxiety to sport performance in competitive male's karateka kumite.

There are three important elements in the karate curriculum namely kihon (basics), kata (forms) and kumite (fight). However these three elements should not be considered separately, because they are a unity and bind strongly one another (Bustami Syam, 2007:14). The karate have two types of competition, they are kumite and kata (Nakayama, 1990:163). Each karateka must taking a part in the nasional or international competition by FORKI (Federasi Olahraga Karate-Do Indonesia) and WKF (World Karate Federation) to get a performance rating. The performance is the result of exercise and learning (Sugiyanto, 1999:83). The maximum achievement can be generated through a long process. Exercise early or starting at a young age is one of the right decision to achieve the maximum performance.

The actualization of three factors (physical, technical and psychological) will show the performance karateka (Pesurnay 2000:172). The mind and mental is more important than the muscle strength. it is proved that the sports performance is not only determined by strength of muscle, but brains and mental also included (Intan Sugih, 2001:1). Readiness of mind and mental turned out to be very beneficial for achieving the higest performance. One of the indicators of stronger mentality is low level anxiety during the fight. Anxiety is the feelings and thoughts associated with doubt and worries. The anxiety indicated by panic, worry, high tension, shortness of breath, nervous, restless, confused, depressed and hasty(Nideffer, 1992: 127). Anxiety is a state of understanding the situation as something that is scary and stress, sometimes the reason can be understood but sometimes not.

The research conducted on athletes in the Olympic Games 1968 shows athletes who have the desire to achieve high performance but have high anxiety will show the decreased performance, but athlete who low anxiety and high achievement motives will show increased performance (Setyobroto, 2009:99). Anxiety divided into two aspects, they are the psychological aspect and physiological aspect. The psychological aspect is anxiety manifests in psychiatric symptoms such as high tense, confused, worried, difficult to concentrate, uncertain feelings, scare, sneaking, easy to get angry, sensitive and so on. Physiological aspects are anxiety that has affected physiological abilities, especially in central nervous system functions such as insomnia, heart palpitations, cold sweat, frequent shaking, queasy stomach, headache, dizziness, tip of finger feels cold, neck muscles rigid and tense, the appetite is lost and so on (Kurniastuti Y, 2004). 
The aggressiveness is a behavior injuring or the intent of someone to hurt (Minarni, 2006:8). (Berkowitz,1995) said the aggressiveness is who states that aggression as behavior intended to hurt someone either physically or mentally. Many sports require aggressive behavior and it is permited to certain level. The sports competitions often triggers aggressive behavior. This behavior at the certain level is necessary for sport player to achieve performance like boxing, karate, football, pencak silat, taekwondo etc. But if it is excessive and cannot be controlled can cause dangerous action, hurt the other person, unsportman, and the other that are not disciplined. The level of aggressive action is different for each sport and also athlete.

R. H. Cox classifies in two categories; hostility aggresion and instrumental aggresion. Hostility agression is the aggressive action that is accompanied by hostility and feeling angry and intending to hurt other people. Instrumental aggresion is aggressive behavior who used as a tool to win the game, without intending to injure another person. Aggression instrumental aims to obtain the victory, money and prestige.

\section{Research Methodology}

One hundred and three males karateka fighters (20 \pm 2 years) participated in this study and they were taken in Kejuaraan Nasional Antar Mahasiswa Sebelas Maret Cup VII in Surakarta. The research of methodology is the correlation descriptive. There are two exogenous variables; anxiety (X1) aggressiveness (X2) and endogenous variable is performance $(\mathrm{Y})$. The anxiety and aggressiveness developed by researchers and tested for their validity and reliability. Performance instruments will calculated by the number of wins karateka. The data will analized with path analysis.

\section{Discussion}

Table 1.Frekuency Distribution of The Level Anxiety Karateka Fighter.

\begin{tabular}{llll}
\hline Interval & Criteria & $\mathrm{f}$ & $\%$ \\
\hline $0-16$ & Low & 5 & 5 \\
$17-31$ & Medium & 70 & 68 \\
$32-47$ & High & 28 & 27 \\
& Sum & 103 & 100 \\
\hline
\end{tabular}

Table 2.Frekuency Distribution of The Level Aggressiveness Karateka Fighter.

\begin{tabular}{llll}
\hline Interval & Kriteria & $\mathrm{f}$ & $\%$ \\
\hline $33-58$ & Very Low & 0 & 0.0 \\
$69-83$ & Low & 0 & 0.0 \\
$84-107$ & High & 5 & 4.9 \\
$108-132$ & Very High & 98 & 95.1 \\
Sum & & 103 & 100 \\
\hline
\end{tabular}


Table 3.The Karateka Fighter Performance.

\begin{tabular}{lllll}
\hline Performance & Frekuency & $\%$ & \\
\hline Never Win & 51 & 49 & \\
Win Once & 28 & 27 & \\
Two Wins & 11 & 11 & \\
Three Wins & 6 & 6 & \\
Four Wins & 6 & 6 & \\
Five Wins & 1 & 1 & \\
$\quad$ Total & & 103 & & 100 \\
\hline
\end{tabular}

The study showed 5 athletes (5\%) had low anxiety levels, 70 athletes (68\%) had moderate anxiety levels and 28 athletes (27\%) had high levels of anxiety. While the level of aggressiveness, there are 98 karateka fighter have a very high level of aggressiveness and only 5 athletes $(4.9 \%)$ are high level, while in the medium and low categories is none at all. Data from athletes performance showed is 51 athletes $(50 \%)$ did not win, 28 athletes $(27 \%)$ won only one, 11 athletes $(11 \%)$ won two times, $6 \%$ won three times, $6 \%$ won four times and one athlete won five times.

The first hypothesis analysis is obtained the coefficient $\beta=-0,274$ and $\mid$ ttest $\mid=2,483$ while $\mid$ tcritical $\mid=1,98$. It can be concluded that there is a direct relationship of anxiety to performance karateka finghter. The regression coefficient marked negative indicates that anxiety is inversely proportional to the performance, the meaning is the high anxiety level make the athlete get lower performance.

The second hypothesis analysis is obtained the coefficient $\beta=0,479$ and $\mid$ ttest $\mid=4,332$ while $\mid$ tcritical $\mid=1,98$. It can be concluded that there is a direct relationship of aggressivity to performance karateka finghter. The regression coefficient marked positive indicates that aggressivity is inversely proportional to the performance, the meaning is the high aggressivity level make the athlete get highest performance. It can be concluded that there is a relationship of direct aggressiveness against the performance of karateka finghter. The regression coefficient is positive shows that the aggressiveness is directly proportional to the achievements, the meaning is the higher the level of aggressiveness of the performance karateka finghter. The regression Model obtained from regression analysis is : $\mathrm{Y}=-7,890$ $0,044 \mathrm{X} 1+0,082 \mathrm{X} 2$. The contribution of two variables can be seen from the R2 value that is 0,507 which means change the performance of karateka fighter, because the factors of anxiety and aggressiveness of $50.7 \%$. The value of the residual of the regression analysis for the regression model is obtained from the formula $\mathrm{e}=0,493$. The results of the path analysis show that the direct contribution of anxiety with performance is $-27,4 \%$ and the direct relationship of aggressiveness with the performance of the karateka is $47.9 \%$.

Before analyzing the indirect relationship between anxiety and performance karateka fighter, previously the relationship analysis of aggressiveness and anxiety completed. The regression model is $\mathrm{X} 2=141,091-0,727 \mathrm{X} 1$ with the value $\mid$ ttest $\mid=12,225$ and $\mid$ tcritict $\mid=1,98$. It can be concluded there is a significant relationship of anxiety to aggressiveness. The negative regression coefficients indicating that if karateka fihgter have the high the anxiety then the the karateka finghter hav lowe the aggressivity. The contribution is 0.597 the mean change in aggressiveness because of the anxiety factor of of $59.7 \%$. The value of the residual of the regression analysis for the regression model is obtained from the formula $e=0,403$. The results of path analysis showed that the contribution of anxiety to the aggressiveness of $-0,772$. 
Table 4.The result of path analysis significance test.

\begin{tabular}{lllll}
\hline Relations & $\beta$ & $\mathrm{t}_{\text {score }}$ & $\mathrm{p}_{\text {value }}$ & Status \\
\hline $\mathrm{X}_{1} \rightarrow \mathrm{X}_{2}$ & $-0,772$ & $-12,225$ & 0,000 & Signifikan \\
$\mathrm{X}_{2} \rightarrow \mathrm{Y}$ & 0,479 & 4,322 & 0,000 & Signifikan \\
$\mathrm{X}_{1} \rightarrow \mathrm{Y}$ & $-0,274$ & $-2,483$ & 0,015 & Signifikan \\
\hline
\end{tabular}

The results of path analysis shows that anxiety is directly related to the male karateka fighter is $-77.2 \%$. Indirectly also relates to performance through aggressiveness as an intervening variable. The anxiety is indirectly related to karatekaperforamance of $-0.72 \mathrm{x}$ $0.479=-0.3698$ or $-36.98 \%$. So if karateka fighter fall on high anxiety directly followed by the low perforamance of athletes and directly the higher the anxiety the lower the aggressiveness and then associated with low performance.

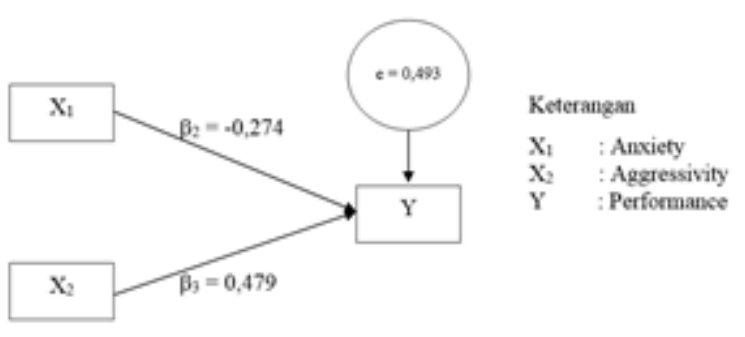

Fig. 1.The Result of Research with Path Analysis

\section{Result}

The results of first regression analysis is $\mathrm{R}$ square value $50.7 \%$. It is mean $50.7 \%$ the performance karateka fighter can be affected by anxiety and aggressiveness. This means that the change in performance achieved by karateka fighter is $50.7 \%$ because of anxiety and aggressiveness, both of which are psychological factors. This data concludes that psychological factors need to be considered. Playing with muscles alone will not achieve good results, playing with the brain is also useless. Physical and psychological factors need to get attention in the framework of systematic and scheduled athlete coaching.

Based on the data obtained, most of the karateka fighter who competed in the national karate championship between students had medium levels of anxiety which reached $68 \%$ and only $27 \%$ were in the high category. This data shows that most athletes are able to control themselves against the anxiety that arises, before competing.RukmiKusningsih, et al (1994: 43), anxiety is a term that is very familiar with everyday life, which describes the state of worry, anxiety, fear, insecurity and so on accompanied by various physical complaints. In general, anxiety is related to threatening and dangerous situations. Usually over time, these conditions will be resolved on their own.

The results of seccond regression analysis showed that anxiety was directly negatively related to athlete's performance. Every change in anxiety that arises will be followed by a 
decrease in achievement of $27.4 \%$. The data shows that anxiety directly contributes to the achievements. Anxiety as a part of psychological factors that often appear every time the competition directly contributes to victory and defeat when competing. Therefore, it is necessary to manage themselves against the emergence of anxiety so that it becomes positive energy to achieve victory when competing.

The results of regression analysis also obtained an illustration that the aggressiveness that appears in athletes is directly proportional to the performance achieved. Every change in aggressiveness towards a higher direction was followed by an increase in achievement achieved with a contribution of $47.9 \%$. Associated with aggressive behavior in this research is instrumental aggressive action with the main goal is to win the match, and not to hurt the opponent. Intention to attack aggressively is not accompanied by anger. Such aggressive action is clearly not caused by frustration. Based on the results of descriptive analysis shows that the level of instrumental aggressiveness is very good, because it is characterized by aggressive behavior to obtain victory and is usually not accompanied by anger. Instrumental aggression is an action that intends to cause pain or damage to others, but where the main goal is not to cause suffering, but to achieve the leading (dominance) or a point/ goal to be able to win the match. With the existence of aggressive behavior that is very good tends to win in the competition.

Based on the results of regression analysis, it shows that anxiety is negatively related to the aggressiveness of the athlete. Every increase in anxiety in the athlete is one unit, followed by a decrease in aggressiveness Aggressiveness decreases because $77.2 \%$ of anxiety factors appear. Looking at this data, it is necessary to foster efforts for athletes to be able to control the anxiety that arises when it will emerge, because it can reduce the aggressiveness of the athlete when competing.

Based on the results of path analysis, it is obtained an illustration that anxiety is indirectly related to achievement, namely through aggressiveness as an intervening variable with a contribution of $-36.98 \%$, while the direct contribution is $-27.4 \%$. Thus anxiety contributes to achievement due to indirect factors. Increasing anxiety arises, followed by a decrease in aggressiveness and finally contributing to the achievement of karate martial arts in male kumite athletes.

\section{Conclusion}

The results of the research and discussion by conclusions are as follows ; (1) There is a direct negative relationship to Karate martial arts achievements in male kumite athletes. The higher achievement is followed by the decrease in the right performance, so that the invert (2) There is a positive direct relation between the level of aggressiveness toward Karate martial arts achievements in male kumite athletes, more and more high the aggressiveness of the athlete, followed by increasing the achievement. (3) There is an indirect relationship between the level of achievement towards Karate martial arts achievements male kumite athletes of negative aggressiveness. The higher the anxiety of the athlete means that the lower the aggressiveness and lower the achievement.

Based on the results of data analysis and research conclusions, suggestions can be made as follows: (1) For the trainer of karate fighter, to improve maximum performance is expected to train and foster athletes who are the main task, not only physical training, technical and tactics, but also pay more attention to the athlete's psychological factors related to anxiety and 
aggressiveness. Because no matter how perfect physical development, technique, and tactics of athletes, if the mentality does not participate develop high achievement will not be possible. Because mental functions as a driver, driver and stabilizer for athletes to embody physical abilities and techniques in achieving prime performance. (2) For the kumite athlete, you should often consult with the trainers when facing problems that can cause anxiety. Athletes should try to suppress anxiety as low as possible by promoting reason and putting aside emotions. Athletes must learn to describe experiences when experiencing anxiety so that the athlete in question understands the symptoms of anxiety and cause and effect they experience. (3) For the Kumite athlete, because aggressive behavior plays an important role in the success of a match, the athlete must understand how to develop and improve aggressive behavior, the athlete must be understand the ways to develop and improve aggressively, keeping it under control so that it cannot be controlled.

\section{References}

[1]Berkowitz, S. 1995. Agresi: sebab dan akibatnya terjemahan (penerjemah: Susianti.H.W.J). Jakarta. Pustaka Psinamon Pressindo.

[2]Bompa. 1994. Theory and Metodology of Training

[3]Bustami Syam. 2007. Teknik Shotokan Karate-Do untuk Kesehatan, Prestasi dan Beladiri.

[4]Husdarta, H.J.S. 2010. Psikologi Olahraga. Penerbit Alfabeta Bandung

[5]Kurniastuti, Y. 2004. Kecemasan Dengan Perilaku Coping Menghadapi Kelahiran Pada Wanita

Hamil.Skripsi. Yogyakarta. Fakultas Psikologi Universitas Sarjanawiyata Taman siswa.

[6]Minarni. 2006. Hubungan Antara Kecemasan Dengan Agresivitas Pada Remaja di SMA Negeri Pangkajene Sidenreng Rappang. Sikripsi. Yogyakarta. Fakultas Psikologi Universitas Sarjanawijawa Taman Siswa.

[7]Nakayama, M. 1990. Best Karate Comprehensive. Penerbit Jelita Bandung

[8]Nideffer Robert M. 1992. Psyched To Win. Illinois: Leisure Press.

[9]Pesurnay, Paulus . 2000. Reposisi Dan Reaktualisasi Sistem Keolahragaan Menuju Indonesia

Baru. Jawa Timur : Panitia Seminar Ilmiah PON XV.

[10]PB. FORKI. 2009. Peraturan Pertandingan Versi 6

Rukmi Kusningsih. 1994. Hubungan Stresor Psikososial Dan Bantuan Sosial Dengan Anxieates Pada Remaja Pelajar 2 SLTA di Yogyakarta (dalam Jiwa Majalah Psikiatri) Jakarta: Yayasan Kesehatan Jiwa Darmawangsa.

[11]Setyobroto S. 1993. Psikologi Kepelatihan. Jakarta: CV. Jaya Sakti.

[12]Sugiyanto. 1999. Belajar Gerak. Surakarta: UNS Press.

[13]Sukadiyanto. 2006. Perbedaan Reaksi Emosional antara Olahragawan Body Contact dan Non Body Contact. Jurnal Psikologi Volume 33, No. 1, 50-62. Yogyakarta: Fakultas Psikologi Universitas Gadjah Mada. 